\title{
New Quinolone Compounds from Pseudonocardia sp. with Selective and Potent Anti-Helicobacter pylori Activity: \\ Taxonomy of Producing Strain, Fermentation, Isolation, Structural Elucidation and Biological Activities
}

\author{
Koen A. DekKer *, Taisuke Inagaki, Thomas D. Gootz ${ }^{\dagger}$, Liang H. Huang ${ }^{\dagger}$, Yasuhiro Kojima, \\ William E. Kohlbrenner ${ }^{\dagger}$, Yasue Matsunaga, Paul R. McGuirk ${ }^{\dagger}$, Etsuko Nomura, \\ Tatsuo SaKakibara, Shinichi Sakemi, Yumiko Suzuki, Yuji Yamauchi \\ and NaKaO KoJima
}

\author{
Central Research Division, Pfizer Pharmaceuticals Inc., \\ 5-2 Taketoyo, Aichi 470-23, Japan \\ ${ }^{\dagger}$ Central Research Division, Pfizer Inc., \\ Eastern Point Road, Groton, CT 06340, U.S.A.
}

(Received for publication October 23, 1997)

\begin{abstract}
Eight novel quinolones with anti-Helicobacter pylori activity were isolated from the actinomycete Pseudonocardia sp. CL38489. The quinolones were very potent against $H$. pylori with MICs up to $0.1 \mathrm{ng} / \mathrm{ml}$. The quinolones appear to be specific for $H$. pylori, since they did not show antimicrobial activity when tested against a panel of other microorganisms.
\end{abstract}

Gastric and duodenal ulcers affect a significant portion of the human population worldwide. Many recent studies have shown a relation between the presence of the microaerophilic, spiral-shaped Gram-negative Helicobacter pylori, which appears to live beneath the mucus layer of the stomach, and gastric and duodenal ulcers ${ }^{1,2}$. One of the most recent progress on $H$. pylori studies is its complete genome sequencing ${ }^{3)}$. Therapy to eliminate $H$. pylori from the gastroduodenal tract would remove the root cause of gastric and duodenal ulcers. Current therapy typically relies upon co-administration of one or more broad-spectrum antibiotics combined with an acid-lowering agent or a bismuth salt. However, even triple therapy is not entirely successful in achieving long term eradication of $H$. pylori. Follow-up of patients cleared of $H$. pylori infection has shown that relapse (rather than reinfection) is a problem. Treatment of $H$. pylori associated gastric disorders with antimicrobial agents given by conventional dosing regimens thus requires a prolonged course of therapy to be effective ${ }^{1,2)}$. However, long-term treatment with current therapies is not recommended in view of side-effects, the build-up of drug resistance and, in particular, the inherent toxicity risk associated with bismuth salts. Accordingly, there is a need for a safe and effective treatment with a compound having excellent anti- $H$. pylori activity. In a screening program designed to discover such compounds from microbial secondary metabolites, the actinomycete Pseudonocardia sp. CL38489 was found to produce new quinolones with anti-Helicobacter pylori activity. In this paper, we report the taxonomy of the producing strain, fermentation, structural elucidation and biological activities of these quinolones.

\section{Producing Strain}

The producing strain, designated as Pseudonocardia sp. CL38489, was isolated from a soil sample collected in India. Cultural characteristics are listed in Table 1. It is distinguished by the white aerial mycelium, the pale yellow to pale orange substrate mycelium, and the fragmentation of both aerial and substrate mycelium into spores. Morphological properties were observed on BENNETT's agar 14 days after inoculation. Vegetative hyphae are branched, measuring $0.6 \sim 1.2 \mu \mathrm{m}$ in diameter, and may fragment into rods or elliptical units. The aerial mycelium is white and sporophores are monopodially branched, occasionally verticillately branched and often aggregated into patches. The spore chains are 
Table 1. Cultural characteristics of Pseudonocardia sp. CL38489.

\begin{tabular}{|c|c|c|c|c|c|}
\hline Medium* & Growth & Texture & Colony surface & Colony reverse & $\begin{array}{l}\text { Soluble } \\
\text { pigment }\end{array}$ \\
\hline ISP Medium $\sharp 2$ & $\begin{array}{l}\text { Good to } \\
\text { moderate }\end{array}$ & $\begin{array}{l}\text { Moderately raised, } \\
\text { smooth to granular }\end{array}$ & White & $\begin{array}{l}\text { Maize yellow (IV) to } \\
\text { light orange yellow } \\
\text { (III) }\end{array}$ & None \\
\hline ISP Medium $\# 3$ & $\begin{array}{l}\text { Poor to } \\
\text { moderate }\end{array}$ & $\begin{array}{l}\text { Thin, smooth to } \\
\text { slightly granular }\end{array}$ & White & Colorless & None \\
\hline ISP Medium $\# 4$ & $\begin{array}{l}\text { Poor to } \\
\text { moderate }\end{array}$ & Thin, smooth & White & Colorless & None \\
\hline ISP Medium $\# 5$ & Good & $\begin{array}{l}\text { Moderately raised to } \\
\text { raised, smooth to } \\
\text { granular }\end{array}$ & $\begin{array}{l}\text { White, capucine buff, } \\
\text { pale orange-yellow } \\
\text { (III), to orange-pink } \\
\text { (II) }\end{array}$ & $\begin{array}{l}\text { Orange-buff (III) to } \\
\text { light orange-yellow } \\
\text { (III) }\end{array}$ & None \\
\hline $\begin{array}{l}\text { Czapek sucrose } \\
\text { agar }\end{array}$ & Moderate & $\begin{array}{l}\text { Thin to slightly raised, } \\
\text { smooth }\end{array}$ & White & Colorless & None \\
\hline $\begin{array}{l}\text { Glucose - } \\
\text { asparagine agar }\end{array}$ & Moderate & $\begin{array}{l}\text { Thin to slightly raised, } \\
\text { smooth to granular }\end{array}$ & White & Colorless & None \\
\hline EMERSON's agar & $\begin{array}{l}\text { Moderate } \\
\text { to good }\end{array}$ & $\begin{array}{l}\text { Moderately raised, } \\
\text { smooth to granular }\end{array}$ & White & $\begin{array}{l}\text { Maize yellow (IV) to } \\
\text { apricot yellow (IV) }\end{array}$ & None \\
\hline BENNETT's agar & Good & $\begin{array}{l}\text { Moderately raised, } \\
\text { smooth to granular }\end{array}$ & White & Capucine buff (III) & None \\
\hline Starch agar & Moderate & $\begin{array}{l}\text { Thin to slightly raised, } \\
\text { smooth }\end{array}$ & White & $\begin{array}{l}\text { Colorless to maize } \\
\text { yellow ((III) }\end{array}$ & None \\
\hline Gelatin agar & Moderate & $\begin{array}{l}\text { Thin to moderately } \\
\text { raised, smooth to } \\
\text { granular }\end{array}$ & White & $\begin{array}{l}\text { Colorless to maize } \\
\text { yellow (III) }\end{array}$ & None \\
\hline
\end{tabular}

straight, wavy or flexuous, with 5 to 30 spores per spore chain, and the spores are oval, elliptical to rod-shaped, $1.2 \sim 1.8 \times 0.8 \sim 1.1 \mu \mathrm{m}$.

Positive physiological reactions of the strain were: production of hydrogen sulfide; nitrate reduction in organic nitrate; hydrolysis of casein, esculin and urea; resistance to lysozyme; formation of acid from glucose and glycerol; utilization of acetate, malate, propionate, pyruvate, succinate, glucose and sucrose; and survival at $50^{\circ} \mathrm{C}$ for 8 hours. The strain did not decompose adenine, elastin, hypoxanthine, xanthine, tyrosine, cellulose, starch and hippurate; it did not clear or coagulate milk; melanin was not produced; nitrate was not reduced from dextrose nitrate broth; gelatin was not liquefied; acid was not produced from adonitol, arabinose, cellobiose, dulcitol, erythritol, fructose, galactose, inositol, lactose, maltose, mannitol, melezitose, melibiose, $\alpha$-methyl-Dglucoside, raffinose, ribose, rhamnose, salicin, sorbitol, starch, sucrose, trehalose and xylose; arabinose, mannitol and xylose were not used as sources of carbon; fructose, inositol, raffinose and rhamnose were doubtfully utilized.

The whole-cell analyses ${ }^{4)}$ of the strain CL38489 revealed the presence of meso-diaminopimelic acid, arabinose and galactose. Thus, it has the type IV cell wall composition and the type A whole-cell sugar pattern. These results, together with the absence of mycolates ${ }^{5)}$ in the cell wall and the presence of menaquinone MK- 8 $\left(\mathrm{H}_{4}\right)$ as the dominant component, indicate that the strain CL38489 belongs to the genus Pseudonocardia, as defined by WARWICK et al. ${ }^{6}$.

Of the four species of Amycolata, the strain CL38489 is somewhat related to $A$. hydrocarbonoxydans, which was recently transferred to the genus Pseudonocardia ${ }^{6}$. They are similar in the colors of the aerial and substrate mycelia, the negative decomposition of adenine, hypoxanthine, tyrosine and xanthine; the negative utilization of benzoate, citrate and mucate; the production of esculinase; and the failure to grow at $5 \% \mathrm{NaCl}$. However, the strain CL38489 differs in failure to liquefy gelatin, positive decomposition of casein, negative hydrolysis of starch, production of urease, resistance to lysozyme and ability to survive at $50^{\circ} \mathrm{C}$. The strain is similar to Pseudonocardia thermophila in being able to survive at $50^{\circ} \mathrm{C}$. The strain CL38489 is considered as a new strain of Pseudonocardia and designated Pseudonocardia sp. It was deposited as FERM BP-4785 at the National Institute of Bioscience and Human-Technology, Agency of Industrial Science and Technology (Tsukuba, Japan). 


\section{Fermentation}

Pseudonocardia sp. CL38489 was maintained on plates of ATCC $\# 172$ agar medium (glucose $1 \%$, dextrin $2 \%$, yeast extract $0.5 \%$, NZ Amine type A $0.5 \%, \mathrm{CaCO}_{3}$ $0.1 \%$ and agar $1.5 \%$ ). A cell suspension from a plate was used to inoculate a $500-\mathrm{ml}$ flask containing $100 \mathrm{ml}$ of Medium-1 (glucose 2\%, Polypepton $0.5 \%$, beef extract $0.3 \%$, wheat gluten $0.5 \%$, yeast extract $0.5 \%$, blood meal $0.3 \%$ and $\mathrm{CaCO}_{3} 0.4 \%, \mathrm{pH} 7.1$ ). The flask was incubated at $26^{\circ} \mathrm{C}$ on a shaker at $250 \mathrm{rpm}$ for 4 days and used to inoculate $7.5 \mathrm{ml}$ into three $500-\mathrm{ml}$ flasks containing $150 \mathrm{ml}$ of Medium-1. These seed cultures were used to inoculate $150 \mathrm{ml}$ into three 6-liter fermentation vessels containing 3 liters of Medium-2 (glucose 1\%, corn starch $2 \%$, wheat embryo $0.5 \%$, NZ Amine type A $0.5 \%$, yeast extract $0.5 \%, \mathrm{CaCO}_{3} 0.4 \%$ and $\mathrm{CoCl}_{2} 0.0001 \%$, pH 6.7). Incubation was carried out at $26^{\circ} \mathrm{C}$ for 9 days with an agitation at 1,700 rpm and an aeration rate at 3 liters per min.

\section{Isolation of Quinolone Compounds}

The combined broth ( 8 liters) of the three 6-liter fermentation vessels was freeze-dried, and the resulting powder dissolved in 4.4 liters of acetone-water $(7: 3)$. The solution was filtered and the filtrate was concentrated to aqueous solution ( 2 liters) which was then extracted with 3.5 liters of ethyl acetate. The extract was dried over anhydrous $\mathrm{Na}_{2} \mathrm{SO}_{4}$ and evaporated to afford an oily residue. The oily residue was loaded on a silica gel column and compounds were eluted stepwise with 1.5 liters of ethyl acetate- $n$-hexane $(1: 1)$, then 1.5 liters of ethyl acetate $-n$-hexane $(3: 1)$ and finally 1.5 liters of methanol. Fractions showing activity were then applied separately to a Sephadex LH-20 (Pharmacia) column and eluted with methanol. Fractions showing activity were further applied to an ODS column (YMC-Pack ODS$\mathrm{AM}, 5 \mu, 20 \times 250 \mathrm{~mm}$ ) and eluted with methanol - water (1:1 to $9: 1$ gradient) for 120 minutes at a flow rate of $10 \mathrm{ml} /$ minute. The detection was made by UV absorbance at $240 \mathrm{~nm}$. The eluted peaks showing activity were collected to yield the compounds CJ-13,136 (1, $26.6 \mathrm{mg}$ ), CJ-13,217 (2, 9.1 mg), CJ-13,536 (3, $1.8 \mathrm{mg})$, CJ-13,564 (4, 1.5 mg), CJ-13,565 (5, 0.6 mg), CJ-13,566 (6, $1.0 \mathrm{mg}), \mathrm{CJ}-13,567$ (7, $11.5 \mathrm{mg})$ and CJ-13,568 (8, $1.8 \mathrm{mg}$ ) (Fig. 1). Separation by analytical HPLC using an ODS column (YMC-Pack ODS-AM, $5 \mu, 4.6 \times 150$ $\mathrm{mm})$ and elution with methanol-water $(4: 1)$ at a flow rate of $1 \mathrm{ml} /$ minute $\left(40^{\circ} \mathrm{C}\right)$ gave the following retention times (minute); 5.4 (1), 6.0 (2), 8.5 (3), 2.7 (4), 4.3 (5),
$4.6(6), 3.5(7)$ and $3.0(8)$.

\section{Structural Elucidation}

The quinolone structures $\mathbf{1} \sim \mathbf{8}$ were elucidated by comparison of ${ }^{1} \mathrm{H}$ NMR (Table 2), ${ }^{13} \mathrm{C}$ NMR (Table 3), UV, IR and MS data (see experimental section) to one another and to the spectral data of known compounds. Molecular formulas were determined by HREI-MS and the number of protons and carbons obtained from NMR data.

${ }^{13} \mathrm{C}$ NMR spectra of $\mathrm{CJ}-13,136\left(1, \mathrm{C}_{20} \mathrm{H}_{25} \mathrm{NO}\right)$ indicated the presence of one carbonyl group and 6 sets of double bonds. ${ }^{1} \mathrm{H}-{ }^{1} \mathrm{H}$ COSY suggested a geranyl group, an allylic methyl and a 2,3-disubstituted-4quinolone as partial structures of $\mathbf{1}$. Literature search for these partial structures gave very good examples to confirm the structure of CJ-13,136. UV, IR, ${ }^{1} \mathrm{H}$ and ${ }^{13} \mathrm{C}$ NMR spectra of antibiotic G1499-2 ${ }^{7)}$ and aurachin $\mathrm{D}^{8,9)}$ corresponded well to those of the quinolone part of 1 . The geranyl group was confirmed by comparison of ${ }^{1} \mathbf{H}$ and ${ }^{13} \mathrm{C}$ NMR data with aurachin $\mathrm{D}^{9)}$ and verapliquinone $^{10)}$. CJ-13,136 must have $E$-configuration at the C-2' double bond, because its ${ }^{13} \mathrm{C}$ NMR signals of C-4' (39.6 ppm) and C-9' (16.5 ppm) correspond to those reported, respectively, and do not match the signals at 31.9 and $23.5 \mathrm{ppm}$ for the $Z$-configuration ${ }^{10)}$. The allylic methyl group must be at $\mathrm{C}-3$ position because its ${ }^{13} \mathrm{C}$ NMR chemical shift at $10.2 \mathrm{ppm}^{7,11)}$, not at C-2 position (around $19 \mathrm{ppm})^{9,12)}$. The major EI-MS fragments of 1 also support the whole structure: $m / z 226\left(\mathrm{M}^{+}-\mathrm{C}_{5} \mathrm{H}_{9}\right)$, $212\left(\mathrm{M}^{+}-\mathrm{C}_{6} \mathrm{H}_{11}\right)$ and $173\left(\mathrm{M}^{+}-\mathrm{C}_{9} \mathrm{H}_{15}\right)$. Thus, the structure of $\mathrm{CJ}-13,136$ was established as shown as $\mathbf{1}$.

The major differences of $\mathrm{CJ}-13,217\left(2, \mathrm{C}_{21} \mathrm{H}_{27} \mathrm{NO}\right)$ from CJ-13,136 (1) are presence of an additional methyl group at $3.71 / 34.8 \mathrm{ppm}$ and lack of a NH-proton on the ${ }^{1} \mathrm{H}$ and ${ }^{13} \mathrm{C}$ NMR, which readily provides the structure of CJ-13,217 as $N$-methyl-CJ-13,136 (2).

The structure of $\mathrm{CJ}-13,536\left(3, \mathrm{C}_{22} \mathrm{H}_{29} \mathrm{NOS}\right)$ was assigned as $N$-(methylthiomethyl)-CJ-13,136 based on the following data: 1) correspondence of ${ }^{1} \mathrm{H}$ and ${ }^{13} \mathrm{C}$ NMR to those of CJ-13,136 except for the lack of an $\mathrm{NH}$-proton and additional signals of isolated methylene at 5.11/49.6 ppm and methylthio group at 2.19/14.4 ppm; 2) $m / z 308\left(\mathrm{M}^{+}-\mathrm{SMe}\right)$ fragment on the EI-MS; 3) NOEs from the methylene at $5.11 \mathrm{ppm}$ to $\mathrm{H}-8$ and $\mathrm{H}-\mathbf{1}^{\prime}$ by the NOE difference spectrum.

The major difference of CJ-13,564 (4, $\left.\mathrm{C}_{21} \mathrm{H}_{27} \mathrm{NO}_{2}\right)$ from CJ-13,217 (2) is the appearance of an C-6 $6^{\prime}, 7^{\prime}$-epoxy moiety $(2.66 / 63.9$ and $58.2 \mathrm{ppm})$ on ${ }^{1} \mathrm{H}$ and ${ }^{13} \mathrm{C} \mathrm{NMR}$, while it lacks the C-6' double bond (5.04/123.7 and 
Table 2. ${ }^{1} \mathrm{H}$ NMR data of quinolones $(\mathbf{1} \sim \mathbf{8})$ in $\mathrm{CDCl}_{3}$ : chemical shifts $(\delta, \mathrm{ppm})$, multiplicity and coupling constants $(\mathrm{Hz})$.

\begin{tabular}{|c|c|c|c|c|c|c|c|c|}
\hline \multirow{2}{*}{$\frac{\text { Position }}{5}$} & \multicolumn{2}{|c|}{ CJ-13,136 (1) } & \multicolumn{2}{|c|}{ CJ-13,217 (2) } & \multicolumn{2}{|c|}{ CJ-13,536 (3) } & \multicolumn{2}{|c|}{ CJ-13,564 (4) } \\
\hline & $8.35 \mathrm{dd}$ & $8.3,1.3$ & $8.47 \mathrm{dd}$ & $8.1,1.6$ & 8.44 brd & 7.8 & $8.47 \mathrm{dd}$ & $8.2,1.7$ \\
\hline 6 & $7.27 \mathrm{dd}$ & $8.3,7.3$ & $7.32 \mathrm{dd}$ & $8.1,6.8$ & 7.32 br t & 7.0 & $7.32 \mathrm{dd}$ & $8.2,6.9$ \\
\hline 7 & $7.50 \mathrm{ddd}$ & $8.1,7.0,1.3$ & $7.60 \mathrm{ddd}$ & $8.4,6.8,1.6$ & $7.60 \mathrm{~m}$ & & $7.61 \mathrm{ddd}$ & $8.8,6.9,1.8$ \\
\hline 8 & $7.17 \mathrm{~d}$ & 8.1 & $7.45 \mathrm{~d}$ & 8.4 & $7.59 \mathrm{~m}$ & & $7.46 \mathrm{~d}$ & 8.4 \\
\hline 9 & & & $3.71 \mathrm{~s}$ & & $5.11 \mathrm{~s}$ & & $3.72 \mathrm{~s}$ & \\
\hline 10 & $2.14 \mathrm{~s}$ & & $2.21 \mathrm{~s}$ & & $2.19 \mathrm{~s}$ & & $2.21 \mathrm{~s}$ & \\
\hline $1^{\prime}$ & $3.47 \mathrm{~d}$ & 7.7 & $3.55 \mathrm{~d}$ & 6.2 & $3.67 \mathrm{~d}$ & 5.7 & $3.58 \mathrm{~d}$ & 6.2 \\
\hline $2^{\prime}$ & $5.33 \mathrm{t}$ & 7.3 & $5.04 \mathrm{~m}$ & & $5.06 \mathrm{~m}$ & & 5.12 br t & 6.2 \\
\hline $4^{\prime}$ & $2.18 \mathrm{~m}$ & & $2.06 \mathrm{~m}$ & & $2.07 \mathrm{~m}$ & & $2.20 \mathrm{~m}$ & \\
\hline $5^{\prime}$ & $2.18 \mathrm{~m}$ & & $2.06 \mathrm{~m}$ & & $2.07 \mathrm{~m}$ & & $1.65 \mathrm{~m}$ & \\
\hline $6^{\prime}$ & $5.11 \mathrm{~m}$ & & $5.04 \mathrm{~m}$ & & $5.06 \mathrm{~m}$ & & $2.66 \mathrm{t}$ & 6.2 \\
\hline $8^{\prime}$ & $1.70^{\mathrm{a}} \mathrm{s}$ & & $1.77^{\mathrm{a}} \mathrm{s}$ & & $1.80^{\mathrm{a}} \mathrm{s}$ & & $1.26^{\mathrm{a}} \mathrm{s}$ & \\
\hline $9^{\prime}$ & $1.71 \mathrm{~s}$ & & $1.56^{\mathrm{a}} \mathrm{s}$ & & $1.57^{\mathrm{a}} \mathrm{s}$ & & $1.81 \mathrm{~s}$ & \\
\hline $10^{\prime}$ & $1.62^{\mathrm{a}} \mathrm{s}$ & & $1.63^{\mathrm{a}} \mathrm{s}$ & & $1.64^{\mathrm{a}} \mathrm{s}$ & & $1.24^{\mathrm{a}} \mathrm{s}$ & \\
\hline
\end{tabular}

\begin{tabular}{|c|c|c|c|c|c|c|c|c|}
\hline \multirow{2}{*}{$\frac{\text { Position }}{3}$} & \multicolumn{2}{|c|}{ CJ-13,565 (5) } & \multicolumn{2}{|c|}{ CJ-13,566 (6) } & \multicolumn{2}{|c|}{ CJ-13,567 (7) } & \multicolumn{2}{|c|}{ CJ-13,568 (8) } \\
\hline & 6.17 brs & & $6.26 \mathrm{~s}$ & & $6.35 \mathrm{~s}$ & & $6.37 \mathrm{~s}$ & \\
\hline 5 & 8.32 br d & 8.1 & $8.43 \mathrm{dd}$ & $8.1,1.4$ & $8.22 \mathrm{dd}$ & $7.8,1.5$ & $8.43 \mathrm{dd}$ & $8.1,1.4$ \\
\hline 6 & $7.30 \mathrm{~m}$ & & $7.35 \mathrm{dd}$ & $7.8,7.0$ & $7.28 \mathrm{dd}$ & $8.0,7.2$ & $7.36 \mathrm{dd}$ & $8.1,7.0$ \\
\hline 7 & $7.55 \mathrm{brt}$ & 7.7 & 7.64 ddd & $8.9,7.0,1.4$ & $7.44 \mathrm{ddd}$ & $8.6,7.2,1.6$ & $7.66 \mathrm{ddd}$ & $8.6,7.0,1.9$ \\
\hline 8 & $7.30 \mathrm{~m}$ & & $7.48 \mathrm{~d}$ & 8.9 & $7.11 \mathrm{~d}$ & 8.6 & $7.48 \mathrm{~d}$ & 8.4 \\
\hline 9 & & & $3.69 \mathrm{~s}$ & & $3.64 \mathrm{~s}$ & & $3.74 \mathrm{~s}$ & \\
\hline $1^{\prime}$ & $3.40 \mathrm{~d}$ & 6.8 & $3.41 \mathrm{~d}$ & 6.8 & $5.44^{\mathrm{a}} \mathrm{d}$ & 7.8 & $6.74 \mathrm{~d}$ & 15.1 \\
\hline $2^{\prime}$ & $5.32 \mathrm{t}$ & 7.7 & $5.20 \mathrm{t}$ & 6.8 & $5.38^{\mathrm{a}} \mathrm{d}$ & 7.6 & $6.35 \mathrm{~d}$ & 15.4 \\
\hline $4^{\prime}$ & $2.13 \mathrm{~m}$ & & $2.07 \mathrm{~m}$ & & $2.05 \mathrm{~m}$ & & $1.70 \mathrm{~m}$ & \\
\hline $5^{\prime}$ & $2.13 \mathrm{~m}$ & & $2.07 \mathrm{~m}$ & & $2.05 \mathrm{~m}$ & & $2.10 \mathrm{~m}$ & \\
\hline $6^{\prime}$ & $5.08 \mathrm{~m}$ & & $5.04 \mathrm{~m}$ & & $5.01 \mathrm{~m}$ & & $5.13 \mathrm{~m}$ & \\
\hline $8^{\prime}$ & $1.72^{\mathrm{a}} \mathrm{s}$ & & $1.71^{\mathrm{a}} \mathrm{s}$ & & $1.68^{\mathrm{b}} \mathrm{s}$ & & $1.68^{\mathrm{a}} \mathrm{s}$ & \\
\hline $9^{\prime}$ & $1.57^{\mathrm{a}} \mathrm{s}$ & & $1.58^{\mathrm{a}} \mathrm{s}$ & & $1.53^{\mathrm{b}} \mathrm{s}$ & & $1.38 \mathrm{~s}$ & \\
\hline $10^{\prime}$ & $1.61^{\mathrm{a}} \mathrm{s}$ & & $1.63^{\mathrm{a}} \mathrm{s}$ & & $1.61^{\mathrm{b}} \mathrm{s}$ & & $1.60^{\mathrm{a}} \mathrm{s}$ & \\
\hline
\end{tabular}

a,b Assignments marked by the same letter are interchangeable in the same compound.

Chemical shifts for NH in 1: 8.17 (br), for 9-SMe in 3: 2.19 (s), for $\mathrm{NH}$ in 5: 8.21 (br), and for $1^{\prime}-\mathrm{OH}$ in 7: 5.17 (br).

$131.9 \mathrm{ppm})$. Proton correlations from COSY and the base peak at $m / z 240\left(\mathrm{M}^{+}-\mathrm{C}_{5} \mathrm{H}_{9} \mathrm{O}\right)$ on EI-MS support the structure 4.

The structure of $\mathrm{CJ}-13,565\left(5, \mathrm{C}_{19} \mathrm{H}_{23} \mathrm{NO}\right)$ was determined by means of ${ }^{1} \mathrm{H}$ NMR comparison to those of CJ-13,136 (1): the appearance of $\mathrm{H}-3$ at $6.17 \mathrm{ppm}$ and the lack of C-10 methyl group at $2.14 \mathrm{ppm}$.

The structure of $\mathrm{CJ}-13,566\left(6, \mathrm{C}_{20} \mathrm{H}_{25} \mathrm{NO}\right)$ was determined by means of ${ }^{1} \mathrm{H}$ NMR comparison to those of CJ-13,217 (2): the appearance of $\mathrm{H}-3$ at $6.26 \mathrm{ppm}$ and the lack of C-10 methyl group at $2.21 \mathrm{ppm}$.

The major differences of $\mathrm{CJ}-13,567\left(7, \mathrm{C}_{20} \mathrm{H}_{25} \mathrm{NO}_{2}\right)$ from CJ-13,566 (6) are: 1) the appearance of hydroxy proton at $5.17 \mathrm{ppm}$; 2) an oxymethine at 5.44 (or 5.38)/ $70.0 \mathrm{ppm}$ which is coupled to $\mathrm{H}-2^{\prime}$ at 5.38 (or 5.44) ppm; 3 ) the disappearance of the methylene at $3.41 \mathrm{ppm}\left(\mathrm{H}-1^{\prime}\right)$.
An NOE was observed between the oxymethine and $N$-methyl group. All of these data confirmed the position of the hydroxymethine, and the whole structure was assigned as 7 .

${ }^{1} \mathrm{H}$ NMR analysis of $\mathrm{CJ}-13,568\left(8, \mathrm{C}_{20} \mathrm{H}_{25} \mathrm{NO}_{2}\right)$, including COSY, and comparison with the compounds $1 \sim 7$ suggested that CJ-13,568 should have one transolefin and $-\mathrm{CMe}(\mathrm{OH})$ - unit between the $N$-methyl-2substituted-4-quinolone and 4-methyl-3-pentenyl groups. Some red-field shifts of the UV absorption maxima compared to those of CJ-13,567 (7) suggest that the quinolone has extended conjugation by the substitution of trans-olefin at C-2 position, which suggests the whole structure to be $\mathbf{8}$. The sequential loss of fragments on EI-MS strongly support the structure: $m / z 228\left(\mathrm{M}^{+}-\right.$ 4-methyl-3-pentenyl group) and $184\left(\mathrm{M}^{+}-\mathrm{C}_{8} \mathrm{H}_{15} \mathrm{O}\right)$. 
Table $3 .{ }^{13} \mathrm{C} \mathrm{NMR}$ data $(\delta, \mathrm{ppm})$ of quinolones $(1 \sim 4$ and 7$)$ in $\mathrm{CDCl}_{3}$.

\begin{tabular}{cccccc}
\hline Position & $\mathbf{1}$ & $\mathbf{2}$ & $\mathbf{3}$ & $\mathbf{4}$ & $\mathbf{7}$ \\
\hline 2 & 145.9 & 150.6 & 149.8 & 150.3 & 155.6 \\
3 & 115.6 & 117.4 & 118.2 & 117.4 & 111.0 \\
4 & 177.9 & 177.2 & 177.4 & 177.2 & 178.4 \\
$4 \mathrm{a}$ & 123.8 & 124.9 & 124.9 & 124.9 & 125.5 \\
5 & $123.4^{\mathrm{a}}$ & $122.8^{\mathrm{a}}$ & $123.6^{\mathrm{a}}$ & $122.8^{\mathrm{a}}$ & $123.6^{\mathrm{a}}$ \\
6 & $126.4^{\mathrm{a}}$ & $127.0^{\mathrm{a}}$ & $127.2^{\mathrm{a}}$ & $127.0^{\mathrm{a}}$ & $125.9^{\mathrm{a}}$ \\
7 & 131.1 & 131.5 & 131.6 & 131.5 & 132.0 \\
8 & 116.6 & $115.0^{\mathrm{b}}$ & $115.6^{\mathrm{b}}$ & $115.0^{\mathrm{b}}$ & 115.2 \\
$8 \mathrm{a}$ & 143.6 & 141.1 & 140.3 & 141.1 & 141.7 \\
9 & & 34.8 & 49.6 & 11.7 & 35.0 \\
10 & 10.2 & 11.6 & 11.5 & 34.9 & \\
$1^{\prime}$ & 30.6 & 30.6 & 30.1 & 30.6 & 70.0 \\
$2^{\prime}$ & 116.6 & $118.3^{\mathrm{b}}$ & $118.6^{\mathrm{b}}$ & $118.7^{\mathrm{b}}$ & $123.0^{\mathrm{a}}$ \\
$3^{\prime}$ & 138.3 & 139.0 & 139.5 & 138.4 & 141.7 \\
$4^{\prime}$ & 39.6 & 39.4 & 39.4 & 36.3 & 39.6 \\
$5^{\prime}$ & 26.4 & 26.4 & 26.3 & 27.4 & 6.1 \\
$6^{\prime}$ & $123.1^{\mathrm{a}}$ & $123.7^{\mathrm{a}}$ & $123.2^{\mathrm{a}}$ & 63.9 & $123.2^{\mathrm{a}}$ \\
$7^{\prime}$ & 132.5 & 131.9 & 131.9 & 58.2 & 132.0 \\
$8^{\prime}$ & 25.8 & 25.7 & 25.7 & 24.8 & 25.7 \\
$9^{\prime}$ & 16.5 & 16.5 & 16.5 & 16.6 & 17.0 \\
$10^{\prime}$ & 17.8 & 17.7 & 17.7 & 18.7 & 17.7 \\
\hline
\end{tabular}

a,b Assignments marked by the same letter are interchangeable in the column.

Chemical shifts for 9-SMe in 3: $14.4 \mathrm{ppm}$.

\section{Biological Properties}

The potencies of the quinolone compounds against $H$. pylori are summarized in Fig. 1. Most potent is the epoxy derivative, CJ-13,564 (4). Alterations of the terpene unit such as a double bond in place of the epoxide (2) and, addition of a hydroxy at $\mathrm{C}^{-1} \mathbf{1}^{\prime}$ (7) or $\mathrm{C}^{-3^{\prime}}$ (8) reduce activity. Quinolones with an $N$-methyl group seem to be more active than those without an $N$-methyl group (1 vs. 5 and 2 vs. 6).

Noteworthy is that no antimicrobial activities were observed at a concentration of $10 \mu \mathrm{g} /$ disk when the quinolone compounds were tested against other microorganisms such as Bacillus stearothermophilus, Micrococcus luteus, Staphylococcus aureus and Pasteurella haemolytica.

Determination of the MBC and MIC of CJ-13,136 against $H$. pylori (Table 4) showed a potent bacteriocidal effect (MBC $10 \mathrm{ng} / \mathrm{ml}$ ), while the bacteriostatic effect was even stronger (MIC $0.1 \mathrm{ng} / \mathrm{ml}$ ).

\section{Discussion}

A frequently encountered problem in antimicrobial screening is the number of hits caused by common antibiotics. For practical reasons we focussed on those hits that were inactive against a panel of Gram-positive and -negative bacteria. An additional advantage of this strategy was that we obtained compounds that, although potent against $H$. pylori, are expected to have less side-effects caused by disturbance of the normal gastrointestinal microbial flora and to contribute less to increased drug resistance of non-target microorganisms.

The new quinolone compounds are structurally related to aurachins $\mathrm{C}$ and $\mathrm{D}^{8)}$, but the position of the terpenoid side-chain is opposite. They also resemble YM-30059 ${ }^{13)}$ and 2-(2-heptenyl)-3-methyl-4-quinolinol ${ }^{11,14)}$, quinolones that have fatty acid-derived side-chains. Many quinolone derivatives have been reported with antimicrobial activities. However, as far as we know, these are the first quinolones reported as $H$. pylori-specific inhibitors. Some quinolone anti-microbials are known to inhibit electrontransport of the respiratory chain ${ }^{8)}$ (note that the quinolones have some similarity to microbial menaquinones). Because the discovered quinolones seem to inhibit an $H$. pylori-specific target molecule which is not critical in the other tested microorganisms, one might speculate that the target is part of the respiratory chain of the microaerophilic $H$. pylori, but is not present in aerophilic microorganism.

It was recognized early that these compounds are amenable to synthesis. The preliminary SAR information obtained from comparison of the described series of natural quinolone derivatives will be of great value during programs aimed at improvement of the in vivo pharmacological profile of the current molecules.

\section{Experimental}

Structural Elucidation

Spectral and physico-chemical data were obtained by the following instruments: UV, JASCO Ubest-30; IR, Shimadzu IR-470; NMR, JEOL JNM-GX270 updated with a LSI-11/73 host computer, TH-5 tunable probe and version 1.6 software; and LREI- and HREI-MS, Hitachi M-80 with an M-003 data processing system. All NMR spectra were measured in $\mathrm{CDCl}_{3}$ unless otherwise indicated and peak positions are expressed in parts per million (ppm) based on the internal standard of the $\mathrm{CHCl}_{3}$ peak at $7.24 \mathrm{ppm}$ for ${ }^{1} \mathrm{H}$ and $77 \mathrm{ppm}$ for ${ }^{13} \mathrm{C}$.

CJ-13,136 (1): Colorless glass; HREI-MS $m / z 295.1924$ (calcd for $\left.\mathrm{C}_{20} \mathrm{H}_{25} \mathrm{NO}, 295.1934\right)$; UV $\lambda_{\max }(\mathrm{MeOH}) \mathrm{nm}$ (ع) 335.2 (9,400), $322.4(9,200), 242.4(26,300)$ and 213.4 $(25,400)$; IR $v_{\max }(\mathrm{KBr}) \mathrm{cm}^{-1} 3425,2925,1634,1604$, 
Fig. 1. Structures and helicobacteriocidal activities of new quinolones $\mathbf{1} \sim \mathbf{8}$.

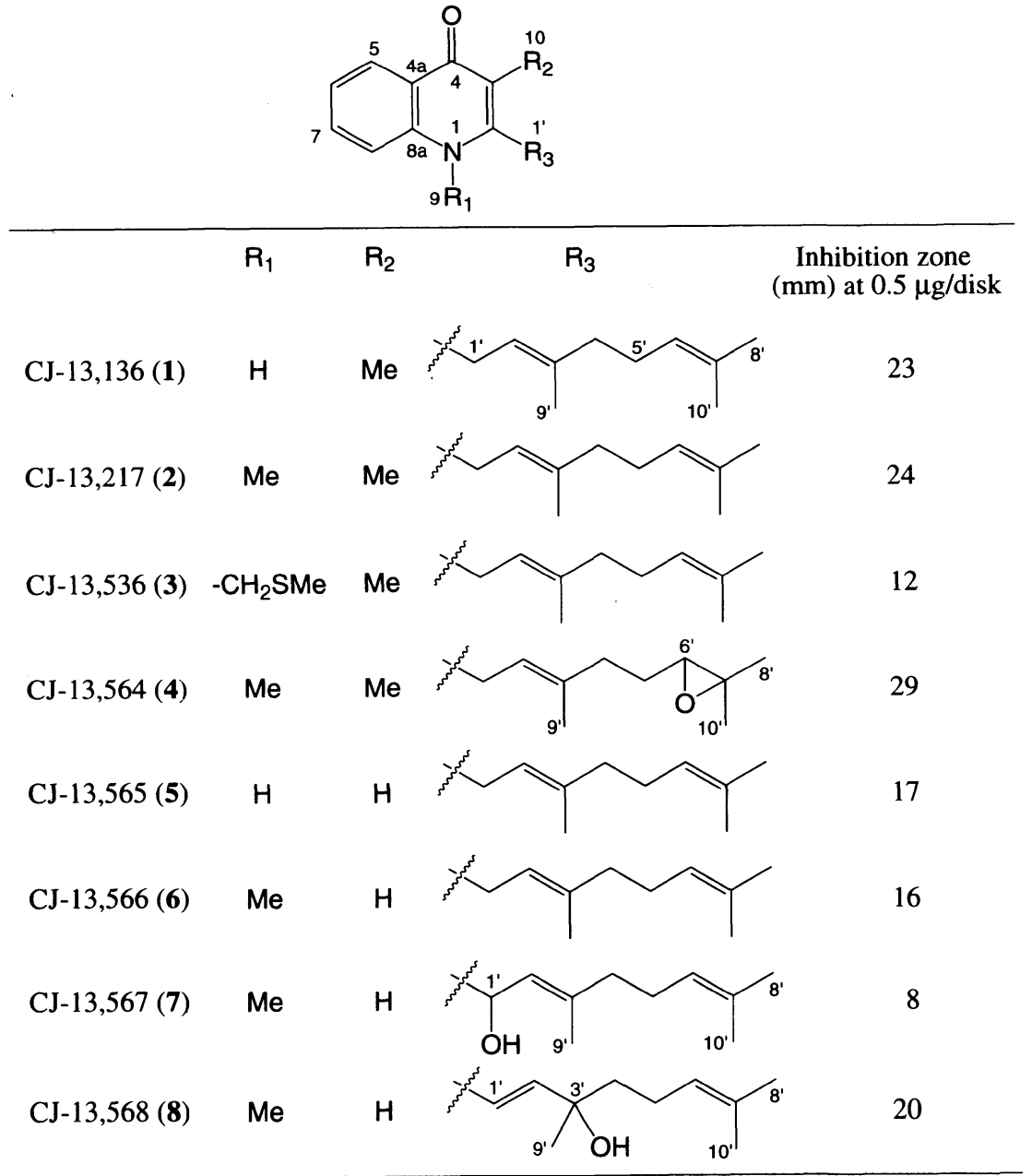

Table 4. Anti-H. pylori MIC and MBC of CJ-13,136.

\begin{tabular}{cccc}
\hline $\begin{array}{c}\text { CJ-13,136 } \\
(\mathrm{ng} / \mathrm{ml})\end{array}$ & $\begin{array}{c}\text { Growth } \\
\left(\mathrm{A}_{590}\right)\end{array}$ & $\begin{array}{c}\text { Survival } \\
(\%)\end{array}$ & \\
\hline $10^{-4}$ & 0.578 & 108.562 & \\
$10^{-3}$ & 0.540 & 90.253 & \\
$10^{-2}$ & 0.282 & 101.131 & \\
$10^{-1}$ & 0.009 & 0.171 & MIC \\
1 & 0.009 & 0.030 & \\
$10^{1}$ & 0.003 & 0.001 & MBC \\
$10^{2}$ & 0.008 & 0 & \\
$10^{3}$ & 0.005 & 0 & \\
\hline
\end{tabular}

Value is an average of triplicates.

$1588,1551,1496,1473,1443,1389,1356,1253,997,753$, 689, 603, 565 and 430; LREI-MS $m / z 295$ (44.3\% rel. int.), 227 (73.5), 226 (100.0), 212 (52.1), 198 (12.0), 184
(21.7), 173 (54.8), 144 (6.9), 130 (5.1), 77 (6.7), 69 (16.4) and 41 (32.4); ${ }^{1} \mathrm{H}$ NMR (see Table 2); ${ }^{13} \mathrm{C}$ NMR (see Table 3).

CJ-13,217 (2): Colorless glass; HREI-MS m/z 309.2086 (calcd for $\left.\mathrm{C}_{21} \mathrm{H}_{27} \mathrm{NO}, 309.2090\right)$; UV $\lambda_{\max }(\mathrm{MeOH}) \mathrm{nm}$ (ع) $344.2(7,000), 331.4(6,400), 247.2(15,700)$ and 213.8 $(16,000)$; IR $v_{\max }(\mathrm{KBr}) \mathrm{cm}^{-1} 2920,1616,1593,1568$, 1541, 1495, 1465, 1366, 1298, 1192, 1108, 1032, 982, 935, 758, 691 and 427; LREI-MS $m / z 309$ (33.1\% rel. int.), 240 (100.0), 226 (29.1), 213 (15.5), 212 (25.3), 198 (37.4), 187 (21.9), 173 (7.4), 77 (7.1), 69 (13.0) and 41 (18.0); ${ }^{1} \mathrm{H}$ NMR (see Table 2); ${ }^{13} \mathrm{C}$ NMR (see Table 3 ).

CJ-13,536 (3): Colorless glass; HREI-MS m/z 355.1952 (calcd for $\left.\mathrm{C}_{22} \mathrm{H}_{29} \mathrm{NOS}, 355.1968\right)$; UV $\lambda_{\max }(\mathrm{MeOH}) \mathrm{nm}$ (ع) $343.8(23,900), 311.2(20,600), 247.4(42,800)$ and 211.6 $(38,100)$; IR $v_{\max }(\mathrm{KBr}) \mathrm{cm}^{-1} 2925,1618,1598,1551$, $1488,1474,1455,1447,1436,1417,1373,1265,1194$, 1156, 1095, 1078, 1049, 1034, 986 and 758; LREI-MS $m / z 355$ (48.8\% rel. int.), 308 (50.5), 294 (12.6), 286 (7.3), 
272 (10.6), 240 (96.8), 226 (19.0), 224 (24.7), 212 (15.9), 198 (33.3), 184 (9.1), 173 (11.3), 132 (11.0), 77 (21.5), 69 (81.7), 61 (100.0) and 41 (59.6); ${ }^{1}$ H NMR (see Table 2);

${ }^{13}$ C NMR (see Table 3 ).

CJ-13,564 (4): Colorless glass; $[\alpha]_{\mathrm{D}}^{25}-17.5^{\circ}$ (c 0.04, $\mathrm{MeOH}$ ); HREI-MS $m / z 325.2060$ (calcd for $\mathrm{C}_{21} \mathrm{H}_{27} \mathrm{NO}$, 325.2041); UV $\lambda_{\max }(\mathrm{MeOH}) \mathrm{nm}(\varepsilon) 344.0$ (15,800), 332.0 $(15,700), 246.0(39,700)$ and $214.4(38,200)$; IR $v_{\max }(\mathrm{KBr})$ $\mathrm{cm}^{-1} 2930,1616,1597,1539,1505,1471,1386,1304$, 1197, 1110,1078 and 760; LREI-MS $m / z 325$ (14.6\% rel. int.), 310 (2.1), 240 (100.0), 226 (14.0), 212 (5.5), 210 (5.2), 198 (17.2), 77 (4.7), 59 (5.0) and 41 (4.6); ${ }^{1} \mathrm{H}$ NMR (see Table 2); ${ }^{13} \mathrm{C}$ NMR (see Table 3).

CJ-13,565 (5): Colorless glass; HREI-MS m/z 281.1788 (calcd for $\mathrm{C}_{19} \mathrm{H}_{23} \mathrm{NO}, 281.1781$ ); UV $\lambda_{\max }(\mathrm{MeOH}) \mathrm{nm}$ (ع) $328.0(12,700), 316.0(13,100), 238.4(34,700)$ and 212.6 $(37,100)$; IR $v_{\max }(\mathrm{KBr}) \mathrm{cm}^{-1} 2920,1643,1597,1547$, $1504,1473,1444,1378,1353,1321,1246,1158,1136$, 1106, 766 and 589; LREI-MS $m / z 281$ (34.1\% rel. int.), 213 (100.0), 212 (56.5), 198 (50.0), 196 (16.9), 172 (28.9), 159 (60.2), 130 (6.7), 89 (6.5), 77 (8.5), 69 (21.5) and 41 (31.5); ${ }^{1} \mathrm{H}$ NMR (see Table 2).

CJ-13,566 (6): Colorless glass; HREI-MS m/z 295.1940 (calcd for $\left.\mathrm{C}_{20} \mathrm{H}_{25} \mathrm{NO}, 295.1935\right)$; $\mathrm{UV} \lambda_{\max }(\mathrm{MeOH}) \mathrm{nm}$ (ع) 335.4 (14,700), $322.8(14,200), 241.6(31,500)$ and 213.6 $(33,400)$; IR $v_{\max }(\mathrm{KBr}) \mathrm{cm}^{-1} 2925,1630,1600,1574$, 1554, 1498, 1470, 1442, 1413, 1276, 1174, 1150, 1106, 1073, 836 and 758; LREI-MS $m / z 295$ (75.0\% rel. int.), 226 (100.0), 212 (92.1), 198 (61.8), 186 (38.7), 184 (63.6), 173 (92.9), 159 (63.6), 144 (13.0), 130 (12.3), 115 (10.1), 89 (14.1), 77 (23.8), 69 (30.5), 53 (11.2) and 41 (73.7); ${ }^{1} \mathrm{H}$ NMR (see Table 2).

CJ-13,567 (7): Colorless glass; $[\alpha]_{\mathrm{D}}^{25}+66.3^{\circ}(c$ 0.575, $\mathrm{MeOH}$ ); HREI-MS $m / z 311.1887$ (calcd for $\mathrm{C}_{20} \mathrm{H}_{25} \mathrm{NO}_{2}$, 311.1883); UV $\lambda_{\max }(\mathrm{MeOH}) \mathrm{nm}(\varepsilon) 336.8$ (17,500), 324.4 (16,400), $242.8(37,000)$ and $213.6(38,000)$; IR $v_{\max }(\mathrm{KBr})$ $\mathrm{cm}^{-1} 3230,2920,1622,1600,1565,1500,1469,1440$, $1414,1383,1346,1306,1267,1202,1175,1154,1087$, 1038, 904, 847, 759, 672 and 469; LREI-MS $\mathrm{m} / \mathrm{z} 311$ (47.7\% rel. int.), 294 (8.6), 243 (51.7), 242 (38.3), 228 (48.1), 226 (100.0), 214 (6.5), 212 (14.1), 210 (9.4), 202 (18.6), 200 (42.7), 198 (28.3), 189 (25.2), 184 (24.1), 174 (15.1), 173 (18.7), 160 (26.4), 159 (46.4), 158 (12.9), 144 (10.9), 130 (15.3), 89 (16.5), 77 (18.1), 69 (29.9) and 41 (64.6); ${ }^{1} \mathrm{H}$ NMR (see Table 2); ${ }^{13} \mathrm{C}$ NMR (see Table 3 ).

CJ-13,568 (8): Colorless glass; $[\alpha]_{\mathrm{D}}^{25}-51.4^{\circ}(c) 0.035$, $\mathrm{MeOH}$ ); HREI-MS $m / z 311.1886$ (calcd for $\mathrm{C}_{20} \mathrm{H}_{25} \mathrm{NO}_{2}$, 311.1883); UV $\lambda_{\max }(\mathrm{MeOH}) \mathrm{nm}(\varepsilon) 338.8$ (15,200), 330 (sh), $252.4(38,600)$ and $218.6(23,500)$; IR $v_{\max }(\mathrm{KBr})$ $\mathrm{cm}^{-1} 3365,2925,1619,1597,1558,1497,1470,1443$,
$1411,1315,1271,1177,1155,1113,1073,1036,978$ and 758; LREI-MS m/z 311 (43.1\% rel. int.), 296 (17.0), 294 (13.3), 252 (15.6), 240 (23.6), 238 (54.5), 228 (27.4), 226 (12.2), 212 (11.3), 210 (13.2), 200 (15.6), 198 (20.1), 186 (100.0), 184 (36.5), 173 (38.5), 159 (11.2), 144 (6.2), 130 (5.3), 115 (6.3), 77 (14.1), 69 (8.7), 55 (14.9) and 43 (15.6); ${ }^{1} \mathrm{H}$ NMR (see Table 2).

\section{Taxonomy}

The media and methods for colony description, utilization of organic acids, carbohydrate utilization, acid production from carbohydrates, temperature studies, resistance to lysozyme, survival at $50^{\circ} \mathrm{C}$, hydrolysis of hippurate and esculin, and decomposition of adenine, hypoxanthine, xanthine, elastin and urea, are those used by Yокота et $a l .{ }^{15)}$. The methods of whole-cell amino acid and sugar analyses are those described in STANECK and ROBERTS ${ }^{4}$. The mycolate analysis was carried out with the method described by LeCHEVALIER et al. ${ }^{5}$. Menaquinones were isolated from 8.8 grams of wet cells killed by addition of formalin to a final concentration of $0.5 \%$ and standing at room temperature for one hour, then the cells extracted with chloroform - methanol $(2: 1)$ and $(1: 2)$ overnight with shaking. The crude extracts were combined, taken to dryness in vacuo at $50^{\circ} \mathrm{C}$, spotted on silica gel TLC with a $254 \mathrm{~nm}$ fluorescent indicator and developed in a hexane : ethyl ether $(85: 15)$ system. UV-absorbing bands comigrating with a standard sample of vitamin $\mathrm{K}_{1}$ were scraped off and eluted with chloroform. The components of these mixtures were determined by the molecular ions present in their mass spectra (HP 5989 Particle Beam Mass Spectrometer).

\section{Antimicrobial Activity}

H. pylori 41, Bacillus stearothermophilus subsp. calidolactis C593, Micrococcus luteus ATCC9341, Pasteurella haemolytica 59B018 and Staphylococcus aureus 01-A-005 were obtained from our culture collection. Stock cultures of $H$. pylori 41 were stored at $-80^{\circ} \mathrm{C}$ in brucella broth (BBL Microbiology Systems) supplemented with $2.5 \%$ heat-inactivated bovine serum and $15 \%$ glycerol. $H$. pylori 41 was grown on brucella agar (BBL Microbiology Systems) supplemented with $10 \%$ FBS. The other microorganisms were grown on Medium 11 (Difco). Antimicrobial activity was tested using paper disks (i.d. $8 \mathrm{~mm}$, Advantec), and activity was observed after 24 -hour incubation at $37^{\circ} \mathrm{C}\left(55^{\circ} \mathrm{C}\right.$ for $B$. stearothermophilus).

For determination of MBC and MIC, $H$. pylori was grown in brucella broth supplemented with $2.5 \%$ FBS 
using shallow petridishes ${ }^{16)}$. Growth was monitored by measuring the absorption at $590 \mathrm{~nm}$, and viability was determined by cfu count of plated 10-fold serial dilutions ${ }^{16)}$.

\section{Acknowledgments}

We thank Professors. G. HöFle and H. ReICHENBaCH for the aurachin samples, and our colleagues Drs./Messrs. C. L. Cummins, N. D. Jankovich, A. Girard and S. L. Haskell for their crucial contributions.

\section{References}

1) BlaSer, M. J.: Helicobacter pylori: Its role in disease. Clin. Infect. Dis. 15: 386 393, 1992

2) Rathbone, B.: H. pylori shakes up the anti-ulcer market. Scrip Magazine April: 25 27, 1993

3) Tomb, J.-F.; O. White, A. R. Kerlavage, R. A. Clayton, G. G. Sutton, R. D. Fleischmann, K. A. Ketchum, H. P. Klenk, S. Gill, B. A. Dougherty, K. Nelson, J. Quackenbush, L. Zhou, E. F. Kirkness, S. Peterson, B. Loftus, D. Richardson, R. Dodson, H. G. KhalaK, A. GlodeK, K. McKenney, L. M. Fitzegerald, N. LeE, M. D. Adams, E. K. Hickey, D. E. Berg, J. D. Gocayne, T. R. Utterback, J. D. Peterson, J. M. Kelly, M. D. Cotton, J. M. Weidman, C. Fujil, C. Bowman, L. Watthey, E. Wallin, W. S. Hayes, M. Borodovsky, P. D. Karp, H. O. Smith, C. M. Fraser \& J. C. Venter: The complete genome sequence of the gastric pathogen Helicobacter pylori. Nature 388: 539 547, 1997

4) Staneck, J. L. \& G. D. Roberts: Simplified approach to identification of aerobic actinomycetes by thin-layer chromatography. Appl. Microbiol. 119: 226 231, 1974

5) Lechevalier, M. P.; A. C. HoRan \& H. Lechevalier: Lipid composition in the classification of nocardiae and mycobacteria. J. Bacteriol. 105: 313 318, 1971

6) Warwick, S.; T. Bowen, H. MCVeigh \& T. M. Embley: A phylogenetic analysis of the family Pseudonocardiaceae and the genera Actinokineospora and Saccharothrix with 16S rRNA sequences and a proposal to combine the genera Amycolata and Pseudonocardia in an emended genus Pseudonocardia. Int. J. Syst. Bacteriol. 44: 293 299, 1994

7) Evans, J. R.; E. J. Napier \& R. A. Fletton: G1499-2, a new quinoline compound isolated from the fermentation broth of Cytophaga johnsonii. J. Antibiotics 31: 952 958, 1978

8) Kunze, B.; G. Höfle \& H. ReichenbaCh: The aurachins, new quinoline antibiotics from myxobacteria: Production, physico-chemical and biological properties. J. Antibiotics 40: $258 \sim 265,1987$

9) Augustiniak, H.; K. Gerth, G. Höfle, H. Irschik, R. Jansen, B. Kunze, H. Reichenbach, H. Steinmetz \& W. TrowitzsCH-KIENAST (GBF mbH): Aurachine, herstellungsverfahren und mittel. DE $3520229 \mathrm{Al}$, June 5, 1985

10) Guella, G.; I. Mancini \& F. Pietra: Verapliquinones: Novel diprenylquinones from an Aplidium sp. (Ascidiacea) of Ile-Verte waters, Brittany. Helv. Chem. Acta 70: $621 \sim 626,1987$

11) Roitman, J. N.; N. E. Mahoney, W. J. Janisiewicz \& M. BENSON: A new chlorinated phenylpyrrole antibiotic produced by the antifungal bacterium Pseudomonas cepacia. J. Agric. Food Chem. 38: 538 541, 1990

12) Claret, P. A. \& A. G. Osborne: NMR spectral studies of some quinolone derivatives. Part III. Carbon-13 magnetic resonance spectral studies of 2- and 4-quinolone derivatives. Spectrosc. Lett. 9: 167 175, 1976

13) Kamigiri, K.; T. Tokunaga, M. Shibazaki, B. Setiawan, R. M. Rantiatmodjo, M. Morioka \& K. Suzuki: YM-30059, a novel quinolone antibiotic produced by Arthrobacter sp. J. Antibiotics 49: 823 825, 1996

14) Hashimoto, M. \& K. Hattori: 2-(2-Heptenyl)-3-methyl4-quinolinol from a Pseudomonas. Chem. Pharm. Bull. 15: $718 \sim 720,1967$

15) Yokota, A.; T. Tamura, T. Hasegawa \& L. H. Huang: Catenuloplanes japonicus gen. nov., sp. nov., nom. rev., a new genus of the order Actinomycetales. Int. J. Syst. Bacteriol. 43: 805 812, 1993

16) IWAHI, T.; H. SATOH, M. NAKaO, T. Iwasaki, T. YAMAZAKI, K. Kubo, T. TAMURA \& A. Imada: Lansoprazole, a novel benzimidazole proton pump inhibitor, and its related compounds have selective activity against Helicobacter pylori. Antimicrob. Agents Chemother. 35: 490 496, 1991 